\title{
Ensino gramatical na classe inferior de gramática da ratio studiorum (1599)
}

\section{Grammatical teaching in the lower class of grammar of ratio studiorum (1599)}

\author{
Janaina Fernanda de Oliveira Lopes*
}

\section{RESUMO}

Este trabalho tem por objetivo discorrer acerca do pensamento linguístico na classe inferior de gramática da Ratio Studiorum (1599). A análise teórico-metodológica se fundamenta nos princípios da Historiografia Linguística, a partir dos pressupostos de Pierre Swiggers (2014) e Konrad Koerner (2014). A discussão se dá no contexto da Reforma Católica e da expansão marítima portuguesa, vinculando o pensamento linguístico à tradição latina. Busca-se, assim, inserir a análise no contexto políticocultural da época e verificar o pensamento linguístico por ela propagado.

Palavras-chave: Gramática. Ensino. Historiografia Linguística.

\section{ABSTRACT}

This work aims to discuss linguistic thinking in the lower grammar class of Ratio Studiorum (1599). The theoretical-methodological analysis is carried out on the principles of Linguistic Historiography, based on the assumptions made by Pierre Swiggers (2014) and Konrad Koerner (2014). The discussion takes place in the context of the Catholic Reformation and the Portuguese maritime expansion, linking linguistic thinking to the Latin tradition. Thus, the paper seeks to insert the analysis in the political cultural contexto of the time and to verify the linguistic thinking spread by it.

Keywords: Grammar. Teaching. Linguistic Historiography.

Recebido em 28 de maio de 2020.

Aceito em 9 de setembro de 2020.

DOI: http://dx.doi.org/10.18364/rc.2021n61.348

*Universidade Federal Fluminense, janainal@id.uff.br, orcid.org/0000-0001-7747-7577

Confluência. Rio de Janeiro: Liceu Literário Português, n. 61, p. 392-413, jul.-dez. 2021 


\section{Introdução}

Pierre Swiggers (2014), ao tratar sobre o objeto e os objetivos da Historiografia Linguística (HL), salienta que, no estudo do conhecimento linguístico, um dos pontos de "ancoragem" para a análise historiográfica reside na história das instituições. Deste modo, neste artigo, busca-se, através da análise dos métodos de ensino da Companhia de Jesus na classe inferior de gramática, ver de que modo esta rede institucional contribuiu com o prosseguimento do conhecimento linguístico vinculado à tradição gramatical latina. Convém mencionar que a Companhia de Jesus foi a responsável pela educação no Brasil por mais de duzentos anos, promovendo, através da Ratio Studiorum (1599), uma educação global.

Com este plano de estudos, a Companhia organizou o seu sistema educacional e trouxe para o Brasil um modelo de ensino vigente na Europa. Os padres jesuítas, cuja formação estava alicerçada no humanismo renascentista, tinham por objetivo catequizar os povos que habitavam as terras recém colonizadas. Para a realização deste propósito, os padres se valeram do ensino, pois acreditavam que o desenvolvimento do ser humano como um todo se dava através da formação nas artes liberais. O propósito da missão jesuítica pode ser visto no regimento da própria Companhia de Jesus, as Constituições.

[307] 1. O fim que a Companhia tem diretamente em vista é ajudar as almas próprias e as do próximo a atingir o fim último para o qual foram criadas. Este fim exige uma vida exemplar, doutrina necessária, e maneira de a apresentar. Portanto, [...] devem-se procurar os graus de instrução e o modo de utilizá-la para ajudar a melhor conhecer e servir a Deus nosso Criador e Senhor.

Para isto a Companhia funda colégios e também algumas Universidades, onde os que deram boa conta de si nas casas e foram recebidos [...] possam instruir-se [...] (Constituições, 2004, p. 115).

A missão, portanto, se baseia na formação dos padres para que estes assumam o papel de propagadores do evangelho através do exemplo 
de vida e do ensino. A formação intelectual jesuítica, então, compreendia uma escolarização que preparasse o homem tanto para a atuação na esfera religiosa quanto na civil. Era, pois, uma formação de caráter duplo, visando ao mundo do trabalho, que serviria aos interesses da Coroa portuguesa, e ao mundo espiritual, resgatando o público que a igreja católica havia perdido no movimento protestantista.

No Estado do Brasil, a catequese e o ensino são práticas socioculturais do chamado "capitalismo monárquico português" na nova situação política mundial determinada pelos Descobrimentos, pela Reforma protestante, pela Contrarreforma e pela disputa comercial e política das potências da Europa pelas possessões coloniais. Iniciado no Estado do Brasil em um momento de aguda crise econômica de Portugal, o programa concilia os interesses da Companhia de Jesus, da Coroa portuguesa e dos coloniais luso-brasileiros (HANSEN, 2010, p. 14-15).

A missão jesuítica está, dessa forma, dentro de um contexto político e sociocultural bastante abrangente, que envolve interesses governamentais e religiosos. Assim, em termos gerais, no que se refere ao princípio da contextualização proposto por Konrad Koerner (2014), o "clima intelectual" da época é marcado pelo cenário de busca do desenvolvimento econômico português, com as grandes navegações, e pela incorporação do pensamento humanista nos métodos de ensino. Ainda a respeito do cenário sociocultural, a educação jesuítica vai prezar por um humanismo voltado ao religioso. Esse fato faz com que os textos utilizados para o ensino nos colégios não promovam o embate com os dogmas religiosos, mas que tratem de questões relativas ao modo de se expressar, de como fazer uso de autores clássicos para desenvolver a "arte do bem dizer".

A importância que a Companhia de Jesus assumiu, diante do cenário político e cultural apresentado, fez com que ela urgisse a organização de um material que conduzisse os preceitos e objetivos da Ordem. Num processo que levou cinquenta e um anos, os jesuítas elaboraram a Ratio Studiorum, cuja 
edição se efetivou em 1599. Esse documento compilou todas as demandas dos colégios e, a partir dele, é possível debater o pensamento linguístico que vigorou dentro dos colégios jesuíticos ao redor do mundo por mais de dois séculos. Esse modelo educacional coloca a educação no Brasil, no período em que os jesuítas estiveram como responsáveis pelo ensino, em paridade com o que havia na Europa, ainda que em teoria. A proposta era a de que todos os alunos no Brasil tivessem acesso aos mesmos conteúdos e métodos dos alunos europeus.

Contudo, a visão humanística de ensino dos jesuítas, ao chegar ao Brasil em 1549, se deparou com um cenário bem diverso do europeu. O Brasil colônia não dispunha dos mesmos recursos que Portugal. Havia carência de várias ordens, como vestuário, alimentação e espaço físico (LEITE, 1938). Esse fato fez com que a missão se voltasse mais para a catequização do que para o ensino propriamente dito, durante todo o século XVI. Assim, o ensino das artes liberais, e consequentemente o ensino de línguas, ficou restrito aos padres que chegavam ao Brasil.

Como dito anteriormente, os jesuítas permaneceram no Brasil por mais de dois séculos, logo, o sistema educacional oferecido por eles iria gerar resultados. Por isso, o debate a respeito do pensamento linguístico e gramatical proposto e efetivado pela Companhia de Jesus torna-se um importante tema, tendo em vista sua relevância no cenário nacional da época e na história da educação brasileira.

A fim de refletirmos acerca do pensamento linguístico apregoado pela Companhia de Jesus, apresentamos, nos próximos tópicos, de que modo o ensino de língua deveria ser ofertado nos colégios jesuíticos. Para tanto, elegemos, dentre as três classes de estudos de latim, a classe inicial, nomeada pela Ratio Studiorum como regulae professoris infimae classis grammaticae, entendendo que, conforme postula Swiggers (2013, p. 42), "os textos que o historiógrafo (ou o historiador) da linguística deve estudar podem ser considerados o 'reflexo (ou depósito) material' da história da linguística". 


\section{Ratio Studiorum: algumas considerações}

Antes de prosseguirmos com a análise da classe de gramática inferior $^{1}$, cabe trazermos uma breve exposição da Ratio Studiorum, a fim de podermos inserir o texto de reflexão dentro de um contexto mais amplo. Com isso, intentamos mostrar que o texto analisado encontra-se dentro de uma perspectiva maior e que ele colabora para a execução de um plano educacional bem mais amplo do que o apresentado aqui.

Como qualquer grande empreendimento, a Companhia de Jesus, com seu exponencial crescimento, precisou elaborar objetivos, meios e regras para o seu funcionamento. O fundador, Inácio de Loyola, desde a criação da Ordem, deixou registrado a necessidade de se elaborar um documento que servisse como norte para o ensino nos colégios. Esse desejo seria efetivado pelo padre Aquaviva ${ }^{2}$, após diversas outras tentativas feitas por outros padres. O plano de estudos da Companhia, a Ratio Studiorum, foi concretizado em 1599 e foi elaborado a partir das experiências de diversos professores de vários lugares. De uma forma geral, o currículo da Ratio pode ser dividido da seguinte forma:

1 O termo "inferior" se refere ao fato dessa classe ser o estudo inicial. Não se deve, portanto, tratá-la como menor ou menos importante.

2 O padre Cláudio Aquaviva foi eleito Geral da Companhia de Jesus em 1581, na Congregação Geral. Ele seria o responsável por acompanhar a comissão que havia sido elegida nesta mesma reunião. Coube a ele conduzir todo o processo de ida e vinda do esboço da Ratio aos colégios até a sua edição final em 1599. Vale mencionar que o plano de sistematizar a Ratio vinha desde 1548, sob a intenção de Jerônimo Nadal (Cf ROSA, 2015; FRANCA, 2019). 
Quadro de divisão do currículo da Ratio Studiorum (1599)

\begin{tabular}{|l|c|}
\hline LETRAS OU HUMANIDADES & 5 anos \\
\hline $\begin{array}{l}\text { Retórica } \\
\text { Humanidades } \\
\text { Gramática Superior } \\
\text { Gramática Média } \\
\text { Gramática Inferior }\end{array}$ & \\
\hline FILOSOFIA OU ARTES & \\
\hline TEOLOGIA & 3 anos \\
\hline
\end{tabular}

No currículo de Letras ou Humanidades, encontramos as classes de gramática. Nossa análise tem por foco a classe de gramática inferior, que era o primeiro seguimento de estudos gramaticais a que os alunos eram submetidos quando entravam no colégio. Para tanto, era necessário que o discente chegasse a esta classe alfabetizado. É importante notar que o tempo de formação nos colégios jesuíticos levava, em média, doze anos de duração.

Conforme o quadro apresentado, a formação oferecida nos colégios da Companhia visava não somente à preparação de um indivíduo no idioma latino. Acima de tudo, intentava a formação de um humanista. Esse aspecto tem por base a formação do fundador da Companhia, Inácio de Loyola ${ }^{3}$, que estudou em colégio e universidade com prerrogativas humanistas. Antes mesmo da formação da Ordem, a Europa vivenciava os ares das humanidades, tendo como grande propagador do ensino humanista o filólogo e teólogo Erasmo de Roterdão. Em Portugal, o humanismo nas instituições de ensino iniciou-se com o envio de "bolseiros" ao colégio francês de Santa Bárbara e com a reforma da Universidade de Coimbra, no reinado de Dom João III.

3 Loyola estudou em Alcalá, numa "recém-criada universidade, fundada pelo arcebispo de Toledo, Francisco Jiménez de Cisneros, e constituía o foco mais importante do humanismo em Espanha" (LOYOLA, 2005, p. 82). Depois, foi para Paris, onde estudou no Colégio de Montaigu e Santa Bárbara. Este último, sendo, entre 1520 e 1548, "o centro mais activo e brilhante do humanismo parisiense" (LOYOLA, 2005, p. 103). 
No espírito da reforma pode vislumbrar-se a tendência ideológica de D. João III, desde logo considerando as ideias dos mestres que, no começo do seu reinado, chamou a Portugal para educação de seus irmãos. Eram portugueses que se distinguiam nas Universidades da Europa, onde se sustentavam as novas ideias humanistas, entendendo-se, por isso, que o monarca procurou 'aqueles em quem encontrava, com mais sólida garantia, as preocupações ideológicas que eram eco das suas próprias' (JACA, 2010, p. 4).

O pensamento de ensino jesuítico estava alicerçado numa visão religiosa, cujo propósito era o de permitir que o homem tivesse o conhecimento sobre o seu Criador através do desenvolvimento da pessoa humana. Neste sentido, ansiavase por uma educação que permitisse ao aprendiz fazer a leitura dos textos sagrados, não com o intuito de rebatê-los, mas de os assimilar conforme havia sido deliberado no Concílio de Trento. Cumpre ter em mente que a aprovação da Companhia pelo Papa se deu dentro do contexto de reforma católica.

Em continuidade à estruturação da Ratio Studiorum, cabe ressaltar que ela é uma compilação de regras para o funcionamento dos colégios da Companhia. Ela indicava o organograma da instituição, o material didático a ser utilizado, os autores a serem estudados, a forma de aplicação de exercícios, a avaliação dos alunos, dentre outras orientações. Grosso modo, podemos dizer que o plano de estudos da Companhia era uma espécie de BNCC (Base Nacional Comum Curricular) da época.

A compilação é formada por 467 regras, divididas em categorias. Inicia-se com as regras para o Provincial, depois, respectivamente, Reitor, Prefeito de estudos, Regras comuns a todos os professores das faculdades superiores, Regras para o professor de Sagrada Escritura, Regras do professor de língua hebraica, Regras para o professor de teologia escolástica e assim por diante. Ao todo, são 27 seções. Essa organização demonstra a preocupação por um ensino unificado, o que permitiria ao aluno ou professor ser transferido para qualquer localidade ou país e ainda assim poder continuar do seguimento em que havia parado. 
Inicialmente, os colégios da Companhia visavam à admissão somente de alunos que quisessem ingressar na Ordem, no entanto, a reforma protestante e a incessante busca pelos colégios fizeram com que os planos fossem mudados. Com isso, a entrada nos colégios também se tornou gratuita. Esse mesmo ideal e modelo de educação vão ser trazidos ao Brasil.

A princípio, contudo, devido à escassez de recursos e ao choque cultural com os indígenas, a missão jesuítica brasileira vai se resumir à catequeseescola. O objetivo da missão era o de aculturar os povos indígenas ao modo de viver europeu, conforme podemos ver em carta de Anchieta datada de 1584.

O método que se adota nestas missões, é ensinar e explicar a doutrina cristã aos Indios e Africanos reunidos em um lugar, batizar, ouvir-lhes as confissões, separá-los das concubinas e sujeita-los ás leis do matrimonio: o que nesta provincia é trabalho quotidiano, necessario e utilissimo á salvação das almas (ANCHIETA, 1933, p. 399).

Ainda com relação à divisão do currículo, o curso de gramática, que daria acesso ao nível superior de 'Filosofia ou Artes', tinha a duração de três anos e poderia ser estendido por mais dois, totalizando cinco. A noção de seriação permitia ao aluno a oportunidade de ter um conteúdo mais humanizado, priorizando a questão qualitativa sobre a quantitativa.

A subdivisão da classe de gramática obedecia ao seguinte critério: um ano de estudo na classe inferior, um na média e um na superior. Caso o aluno não conseguisse atingir os objetivos propostos na classe inferior ou na média, ele poderia cursar mais um ano em cada uma. Somente na superior essa possibilidade era vetada.

As aulas ocorriam de segunda a sábado. O tempo era dividido da seguinte maneira: duas horas e meia durante a manhã e duas horas e meia durante a tarde, totalizando cinco horas diárias. A modalidade de estudos almejada era o de internato, mas a Companhia admitia alunos externos. Aos sábados, ocorriam a sabatina e os desafios, em que competições entre os colégios eram estimuladas. 
Os autores que deveriam ser trabalhados nas aulas variavam. $\mathrm{Na}$ classe inferior, estudavam-se as cartas mais fáceis de Cícero; na média, as cartas de Cícero aos familiares e Ovídio; na superior, Cátulo, Tibulo, Virgílio, dentre outros.

Para entender a divisão das classes de gramática, é imprescindível ter uma noção da gramática de Manuel Álvares, De institutione grammatica libri tres (1572). Esse compêndio de língua latina é dividido em três livros e, de modo geral, cada livro é o centro dos estudos em cada classe de gramática. Em virtude disso, a obra de Álvares se tornou uma das mais editadas gramáticas do mundo (MIRANDA, 1995; KEMLLER, 2013). O seu uso era recomendado no plano de estudos da Companhia, conforme podemos notar na regra de número 23 para o Provincial.

23. Gramática do P. Manuel Álvares. - Cuide que os nossos professores adotem a gramática do P. Manuel [Álvares]. Se em algum lugar o seu método parecer muito elevado para a capacidade dos alunos, adote então a gramática romana, ou, após consulta do Geral, mande compor outra semelhante, conservando sempre, porém, a importância e propriedade de todas as regras do P. Álvares (FRANCA, 1952, p. 128; FRANCA, 2019, p. 98).

A gramática latina de Álvares pôde contribuir para a unificação do ensino gramatical, visto que, antes da sua elaboração, diversas gramáticas de Latim eram utilizadas na época (Cf MIRANDA, 1995; SPRINGHETTI, 19611962). Almeida Navarro (2000, p. 396) destaca que "adotou-se a gramática de Despautério em Portugal, desde o início, nos colégios da Companhia de Jesus, e ainda continuava em uso quando Manuel Álvares publicou sua célebre gramática, isso em 1572."

\section{Classe de gramática inferior}

Primeiramente, para ter acesso a este nível de escolaridade, o aluno precisaria estar alfabetizado, ou seja, deveria ser conhecedor do alfabeto 
latino. Ao ingressar na primeira classe de gramática, o professor apresentaria ao discente o primeiro livro da gramática de Manuel Álvares.

[...] Começa com as declinações e vai até a construção comum dos verbos. Onde houver duas subdivisões, na subdivisão inferior se explicarão, do primeiro livro, os nomes, verbos, as regras fundamentais, as quatorze regras da construção, os gêneros dos nomes; na superior do primeiro livro a declinação dos nomes sem os apêndices, e ainda os pretéritos e os supinos; [...] (FRANCA, 2019, p. 165).

Esta classe tinha por objetivo apresentar a Etimologia da língua latina, que corresponde ao que denominamos Morfologia atualmente. Essa parte compreende as classes de palavras, divididas da seguinte forma: nome, pronome, verbo, particípio, preposição, advérbio, interjeição e conjunção (FERNANDES, 2007). Tal empreendimento propiciaria ao discente a formação necessária para que ele tivesse acesso ao estudo da sintaxe posteriormente.

O método de ensino gramatical de Álvares era baseado na descrição e apresentava, conforme assevera Cardoso (1995), a junção do usus e do ratio, configurando, assim, uma gramática de cunho pedagógico.

[...] a gramática do séc. XVI, ainda e por excelência a 'gramática latina', estabelece um compromisso e faz com que a síntese entre o usus e a ratio, critérios necessários para sustentar cientificamente toda a doutrina gramatical. Estes critérios são a tentativa, julgo que bem conseguida, de estabelecer um equilíbrio entre a teoria especulativa dos modistas e o labor filológico dos gramáticos do séc. XV. [...] (CARDOSO, 1995, p. 160).

Não é propósito deste artigo adentrar na gramática alvaresiana, mas se valer dela para apresentar o pensamento linguístico jesuíta que vigorou na Ratio Studiorum e foi propagado em diversas partes do mundo através dos colégios jesuíticos.

As orientações que são dadas ao professor desse seguimento são divididas em nove regras. A primeira, como já mencionado, contém o objetivo 
do curso, que é o de proporcionar aos alunos "o conhecimento perfeito dos elementos da gramática e inicial da sintaxe" (FRANCA, 2019, p. 165). Em seguida, são dadas orientações para a divisão do tempo. Neste momento, é possível perceber a tentativa de uma aula versátil, pois busca-se preencher o tempo com práticas dinâmicas, o que poderia atrair a atenção dos alunos. Essa atitude diferencia o ensino jesuítico do modelo estritamente escolástico.

2. Divisão do tempo. - O tempo dividir-se-á do seguinte modo. $\mathrm{Na}$ primeira hora da manhã recitação de cor, aos decuriões, de Cícero e da gramática, correção pelo professor dos trabalhos escritos recolhidos pelos decuriões, enquanto os alunos se ocupam em outros exercícios mencionados na regra 4. Na segunda hora matutina, repetição rápida da última preleção de Cícero, explicação, por meia hora, da nova que será logo objeto de interrogação, e finalmente, ditado do tema.

[...] a última meia hora da manhã, porém, seja sempre empregada toda em desafio ou exercício de aula (FRANCA, 2019, p. 165).

A terceira regra aponta para a forma de correção dos trabalhos escritos. Neste momento, cabia ao professor apontar as falhas que o aluno tivesse cometido quanto à gramática, à ortografia e à pontuação. A orientação era para que o professor sempre fizesse as correções seguindo os preceitos da gramática. Desse modo, não cabia ao mestre questionar outros usos, o que valia era o latim utilizado pelos autores clássicos e descrito na gramática alvaresiana.

Álvares deixa bem claras as suas influências, ao citar Aristarco, Diomedes e Donato. Simão Cardoso (1995) ainda aponta outra fonte utilizada pelo gramático, ao analisar o que Álvares diz, quando se refere às palavras que são declináveis, ele (1995, p. 164) verifica que "na justificação que apresenta [Álvares] utiliza os mesmos critérios de Varrão". Ocorre, dessa maneira, ainda nas palavras de Cardoso (p. 165), que "Álvares apresenta uma classificação das 'partes orationis' com uma base gramatical que radica na gramática do período latino após Varrão".

Confluência. Rio de Janeiro: Liceu Literário Português, n. 61, p. 392-413, jul.-dez. 2021 
A regra de número quatro trata dos exercícios que deveriam ser passados enquanto o professor estivesse ocupado corrigindo os trabalhos que os alunos haviam feito em casa. Do mesmo modo que a gramática de Álvares, podemos ver o pensamento linguístico exposto nessa classe de gramática através de exercícios que mostram o descritivismo linguístico.

4. Exercícios durante a correção dos trabalhos escritos. - Enquanto corrige os trabalhos escritos, poderá o professor passar aos alunos os exercícios seguintes: verter para o latim um ditado vernáculo de acordo com as regras da sintaxe, traduzir um trecho de Cícero do latim para o vernáculo e em seguida retrovertê-lo para o latim; [...] (FRANCA, 1952; 2019).

O ponto central deste curso era o ensino de gramática. Por causa disso, como aponta a regra de número cinco, o professor poderia estimular o interesse dos alunos, fazendo-os "declinar, conjugar e interrogar gramática de todos os modos" (FRANCA, 2019, p. 166), durante a preleção da gramática. O ensino se dava pelo método de perguntas e respostas e buscava que o aluno tivesse o máximo possível de contato com a língua latina. No entanto, por ser essa uma classe introdutória, a explicação das regras gramaticais e os exercícios poderiam ser ministrados na língua vernácula, mas sempre acompanhado da exposição em latim. O ensino abarcava não somente a memorização de regras gramaticais, por meio de recitação e sabatinas, mas também a literatura. Esse modo de educação contemplava a formação linguística do estudante nas esferas gramatical e literária.

6. Preleção dos autores. - A preleção de Cícero, que por via de regra não excederá quatro linhas, obedecerá ao método seguinte: Em primeiro lugar leia seguidamente todo o trecho e indique, resumidamente, em vernáculo, o sentido. Em seguida traduza o período no idioma pátrio, palavra por palavra. [...] explique as metáforas com exemplos muito acessíveis e não dite cousa alguma, a não ser talvez o argumento. Em quarto lugar percorra de novo o trecho do autor em vernáculo (FRANCA, 1952; 2019).

Confluência. Rio de Janeiro: Liceu Literário Português, n. 61, p. 392-413, jul.-dez. 2021 
A respeito do princípio da imanência postulado por Koerner (2014), a classe inicial de gramática latina deveria também propiciar aos discentes o conhecimento introdutório da sintaxe: "do livro segundo, a introdução à sintaxe sem os apêndices ${ }^{4}$ até aos verbos impessoais" (FRANCA, 2019, p. 165). Para Álvares, "sintaxe" é o mesmo que "construção", sendo "syntaxis Graece, Latine constructio est recta partium orationis inter se compositio" (ÁLVARES, 1572 apud FERNANDES, 2007, p. 93). Assim, sintaxe é "a correcta interligação das partes do discurso" (FERNANDES, 2007, p. 93). Por ser uma classe introdutória, os exercícios escritos não deveriam ser extensos e deveriam proporcionar meios de se aplicar as regras da gramática.

7. Assunto dos exercícios escritos. - O assunto de exercício escrito deverá ser ditado, palavra por palavra, em vernáculo; ser claro, não exceder, geralmente, quatro linhas e servir principalmente à aplicação das regras de gramática. Às vezes poderá mandar-se aos alunos que transcrevam alguma versão curta de Cícero, ou alguma expressão para aplicação das regras de sintaxe, [...] (FRANCA, 2019, p. 167).

Ao estudar a língua latina, o aluno acabava por se aprofundar na sua língua vernácula, uma vez que o conhecimento da língua estrangeira permitiria que ele verificasse o funcionamento da sua própria língua. $\mathrm{O}$ ato de ouvir e escrever o exercício que era ditado, mais as decúrias que os alunos faziam, corroboravam uma aprendizagem tríade, pautada na leitura, na escrita e na fala.

A penúltima regra trata da preleção da gramática, que deveria ser breve. A orientação era a de que fosse exposta apenas uma regra por dia. Para a fixação dela, o professor deveria lembrá-la durante os exercícios escritos, nos desafios, na preleção dos autores e mesmo na repetição que os alunos

4 Os apêndices que a Ratio menciona se referem à parte de acréscimo que Álvares fez por toda a gramática. Eles tratam de assuntos pormenorizados para as classes seguintes e também auxiliam o professor, pois são compostos por explicações filológicas.

Confluência. Rio de Janeiro: Liceu Literário Português, n. 61, p. 392-413, jul.-dez. 2021 
faziam ao início de cada aula. A preleção não se tratava de uma simples explicação, ela permitia que o aluno tivesse um momento de análise acerca do modo como a língua opera, o seu funcionamento.

A regra de número nove trata dos meios para a fixação da aprendizagem. Esse poderia ser considerado um momento de descontração, em que os alunos fixariam o conteúdo de forma interativa.

9. Desafio. - O desafio ou exercício de aula poderá versar sobre as faltas que um êmulo descobriu nos trabalhos escritos do outro, sobre questões relativas aos pontos em que se exercitaram na primeira hora, sobre perguntas de locuções vernáculas para aplicação de uma regra de sintaxe (procure-se que o interrogado repita imediatamente, com as mesmas palavras, a expressão proposta e depois de breve reflexão a enuncie quanto possível, não palavra por palavra, mas toda, de uma só vez, em latim), sobre as flexões de nomes e verbos mais difíceis, especialmente dos que ocorreram na preleção, conservando ou saltando a ordem dos casos e tempos, declinando os nomes isolados ou articulando substantivos, adjetivos e pronomes, sobre a recitação das definições das noções elementares, ou exemplos, sobre a versão rápida das formas verbais do latim para o vernáculo e vice-versa, sobre transposição da voz ativa para a passiva, sobre a indicação dos pretéritos e supinos, dos gêneros e casos dos nomes propostos e outros exercícios semelhantes a critério do professor (FRANCA, 2019, p. 167).

Além dos exercícios em sala de aula e dos desafios, os alunos eram submetidos a exames escritos. Essas provas deveriam seguir os seguintes critérios: "Para o exame em todas as classes haja um, ou se for mister, dois trabalhos de prosa;" (FRANCA, 2019, p. 132). Há a preocupação em não sobrecarregar o aluno e em avaliar não somente a gramática, mas também a aprendizagem literária.

Ainda com relação ao ensino gramatical na classe de gramática inferior, podemos notar, por meio da análise do método de ensino linguístico, o diálogo da educação jesuítica com o modus parisienses. 
Ocorre que já existia, desde os fins do século 14 nos Países Baixos e na Alemanha, certa variedade de escolas ao redor das Fraternidades dos Irmãos de Vida Comum, fundadas por Gerard Groot (1340-1384). Os elementos característicos nas escolas destes irmãos eram a divisão dos estudantes por classes, cada uma com um mestre e um programa preciso, ordenado e progressivo. Empregavam, também, o Quadrivium -aritmética, música, geometria e astronomia -, sendo que cada matéria tinha um professor especializado e as mesmas eram coordenadas com outras disciplinas ensinadas na mesma escola. Além disso, utilizavam a Bíblia para a formação dos jovens no ideal de vida cristã para o qual todas as ciências e letras deveriam estar direcionadas. Outros elementos típicos de sua pedagogia eram a adoção do sistema de decúrias, o exame de passagem para o nível de estudos literários, o cultivo da língua vernácula, os emolumentos para os melhores estudantes, o teatro escolar, as punições e as disputas (STORCK, 2016, p. 143).

Com isso, podemos dizer que os jesuítas se valeram de um modelo bastante difundido e o adaptaram aos seus colégios, trazendo, dessa forma, uma concepção de ensino que vigorava ao menos dois séculos antes. Em seu plano de estudos, o modus parisiensis aparece na divisão das classes de ensino, através de turmas seriadas pelos níveis de aprendizagem, como já vimos na divisão das classes inferiores e média, em tópico anterior. Ele também fica manifesto nas regras para a divisão do tempo, nos exercícios em sala de aula, na preleção da gramática e nos desafios.

Até o momento, tecemos considerações a respeito do ensino da língua latina. Contudo, a Ratio também apregoa o estudo do grego. Enquanto o latim era estudado como uma língua de cultura, pois há muito tempo ele não era uma língua de comunicação, o grego serviria como meio de facilitar a leitura das Sagradas Escrituras. Essa formação ia ao encontro do caráter humanista religioso da Companhia, completando, dessa forma, um ensino que abarcava a formação intelectual e espiritual.

Como já elucidado anteriormente, o humanismo em Portugal, e consequentemente incorporado pela Companhia de Jesus, foi o vinculado à questão religiosa. Esse pensamento vai ser propagado também nos colégios

Confluência. Rio de Janeiro: Liceu Literário Português, n. 61, p. 392-413, jul.-dez. 2021 
jesuíticos e está explícito na classe de gramática inferior, quando orienta a respeito das atividades do colégio nos dias de sábado: "na última meia hora, explicação de catecismo ou exortação espiritual, salvo quando tenha sido feita na sexta feira; neste caso, empregue-se o tempo no estudo daquilo que cedeu o lugar ao catecismo" (FRANCA, 2019, p. 166).

A respeito do grego, temos a seguinte recomendação: "Em grego, a subdivisão mais atrasada aprenderá a ler e escrever, a mais adiantada os nomes simples, o verbo substantivo e o verbo barítono" (FRANCA, 2019, p. 165). A edição da Ratio de 1599, diferentemente do que fala com relação ao latim, não indica qual gramática deveria ser usada no ensino da língua grega. Porém, Almeida Navarro (2000, p. 389), retomando Rodrigues (1981, p. 439), esclarece que "entre os jesuítas, por exemplo, a gramática grega de Clenardo foi adotada desde o começo como livro de texto em seus colégios". Navarro ainda elucida que:

Importa dizer que a edição lisboeta de 1595 da gramática grega de Clenardo (e a primeira que se conhece de prelos portugueses) foi mandada compor para uso da Companhia de Jesus, cujo monograma aparece estampado no frontispício da obra. O grego que se aprendia no âmbito da Companhia de Jesus era-o com a gramáticas de Clenardo, como anteriormente já se viu, e isso até o século dezoito, quando a gramática de Port Royal assumiria a primazia no ensino da língua helênica naquele país. Conhecem-se edições setecentistas portuguesas da gramática grega de Clenardo, de 1702 e de 1729 (NAVARRO, 2000, p. 390).

A obra de Clenardo vai, portanto, vigorar por, pelo menos, dois séculos nos colégios da Companhia de Jesus.

A respeito do método pedagógico de Clenardo, sua visão de ensino estava pautada no aluno, conforme menciona Morais.

Tendo sempre como centro das suas preocupações o aluno, preconizava um ensino que não sobrecarregasse a memória deste com minudências gramaticais ou regras inúteis, que fosse vivo e intuitivo e que se pautasse pela clareza e pela simplicidade de processos (MORAIS, 2009, p. 118). 
Navarro ainda acrescenta:

Clenardo preconizava um ensino de línguas clássicas como se elas fossem línguas vivas; esse seria feito de modo ameno, viva e intuitivamente, sem o recurso à memorização forçada de regras gramaticais, mas, sim, ao ensino direto, visando ao aprendizado pela prática, de forma ordenada, clara e simples (NAVARRO, 2000, p. 387).

Com efeito, a aceitação da gramática de Clenardo se deu por seu valor pedagógico, enriquecido pela sua prática docente. A edição de 1549 pode ser dividida em quatro partes 5 .

A primeira [...] é a mais extensa, contendo o fundamental para a leitura e entendimento dos textos por parte dos que se iniciavam na língua de Homero: o alfabeto, as regras da pronúncia e o essencial relativo às oito partes em que os antigos, desde Dionísio da Trácia, autor da primeira gramática grega, dividiam a oração (nome, verbo, particípio, pronome, artigo, advérbio, conjunções e preposições). Na segunda parte [...], inclui o autor algumas notas sobre os adjectivos e sobre as declinações e insere ainda breves capítulos sobre os numerais, os graus de comparação, os nomes verbais (verbalia) e os nomes heteróclitos (heteroclita). Na terceira, [...], apresenta uma listagem de verbos anómalos com a enunciação dos seus principais tempos. Para a quarta e última parte [...], a exposição de umas quantas regras de sintaxe, sucintas e não muito numerosas (MORAIS, 2009, p. 119).

O ensino do grego buscava uma simplificação da língua, a fim de que a sua apreensão fosse facilitada. Diferentemente da gramática alvaresiana,

5 Posteriormente, os jesuítas irão utilizar edições da gramática de Clenardo de prelos portugueses. Esses aditamentos se afastam, em alguns aspectos, da edição princeps de 1549. As edições portuguesas são ainda mais sucintas e se adaptam aos moldes da Companhia de Jesus, trazendo, como mostra Carlos Morais (2009, p. 129), "tradução das formas verbais para vernáculo". O autor ainda faz uma síntese das três edições, 1594,1595 e 1608.

Confluência. Rio de Janeiro: Liceu Literário Português, n. 61, p. 392-413, jul.-dez. 2021 
Clenardo compôs um compêndio bem menor, visando mais precisamente ao uso do que explicações filológicas. Ainda segundo Morais, Clenardo (2009, p. 119) "procurava pôr em destaque, sobretudo, alguns dos aspectos em que o grego diferia do latim [...]."

Nesse sentido, vemos que, para o ensino de grego, a Ratio pontua, na segunda regra, que trata da divisão do tempo, que deveria haver recitação da gramática grega, assim como da latina, no período da tarde. A recitação e a explicação tanto do latim quanto do grego se davam em sequência. O ensino pode ser visto como complementar. Nessa classe também esperavase que o aluno já saísse conhecedor da sintaxe grega. O plano de estudos da Companhia informa que deveria ser guardado ao menos um quarto de hora, ou seja, um pouco mais de quinze minutos. Talvez o ensino concomitante ao latim permitisse a aprendizagem do grego, visto tão reduzido tempo. Convém ressaltar que a Ratio é produto da prática docente ao longo dos anos nos colégios jesuíticos.

Os exercícios a serem feitos durante a aula, conforme indica a regra de número quatro, demonstram o ensino ainda pautado na escolástica: "das regras de gramática, sobretudo das explicadas recentemente, recolher dificuldades ou expressões para propor aos êmulos, articular ou compor concordâncias, copiar grego, e outros semelhantes" (FRANCA, 2019, p. 166).

No que concerne ao assunto dos exercícios escritos, regra de número sete, há a sugestão de se copiar o conteúdo que seria dado a respeito do grego. $\mathrm{O}$ ensino dessa língua baseia-se na memorização e na repetição das regras. A preleção da gramática deveria seguir as mesmas instruções que foram dadas para o latim, já que a regra de número oito não menciona algo específico para a gramática grega.

A gramática de Clenardo ainda apresenta um aspecto bastante importante dentro do contexto dos colégios jesuíticos. A edição de 1594 , conforme apresenta Morais, mostra-nos o quanto o estudo do grego estava atrelado ao religioso. 
Seguem-se-lhe, já à margem do texto gramatical clonado, as orações do Pai-Nosso (Oratio Dominica), da Ave-Maria (Salutatio Angeli ad Beatissimam Virginem), da Salve-Rainha (Salue Regina) e do Credo (Symbolum Apostolorum) e ainda um passo do prólogo do Evangelho Segundo S. João sobre o Verbo Divino (Jo. 1. 1-14), acompanhados pelas respectivas traduções latinas (MORAIS, 2009, 122).

A colocação de elementos religiosos nesta gramática coopera para inculcar o pensamento cristão na hora de uma consciência metalinguística. $\mathrm{O}$ credo e as orações também eram uma forma de memorização, já que eles faziam parte da vida cristã cotidiana. A partir deles, era possível até mesmo fazer uma introdução acerca do ensino gramatical, como ocorreu na missão no Brasil, cujo objetivo foi a catequese escola. Ou seja, os indígenas aprendiam o credo sem nem mesmo ter o conhecimento da língua. É importante frisar que a concepção de ensino daquela época não é a mesma atualidade, visto que aquela sociedade concebia o ensino juntamente com a prática religiosa, tendo em vista os contextos social e cultural do século XVI (HANSEN, 2010).

Em suma, a Companhia de Jesus, através dos seus colégios, vai levar para diversas partes do mundo uma visão de língua alicerçada no humanismo renascentista, tendo como base a vertente cristã católica.

\section{Conclusão}

O pensamento linguístico promovido pela Companhia de Jesus, através dos seus colégios, reflete um grande compromisso com o ensino. A temática do estudo gramatical aliado a um texto literário é, pois, uma preocupação que vigora não somente em relação aos estudos de língua materna, mas também em relação a uma segunda língua.

Os jesuítas, mesmo não se distanciando totalmente da escolástica, intentaram e promoveram um ensino particular, pois vincularam o pensamento humanista renascentista da época a uma concepção de ensino pautada no objetivo de desenvolvimento do ser humano através da literae. 
Além disso, o contexto de formação dos colégios, tendo como pano de fundo a reforma católica e a expansão da Coroa portuguesa por meio da colonização, trouxe a preocupação de um ensino que servisse não somente à questão religiosa, mas também à econômica. Atualmente, é possível vermos essa visão de educação nas diretrizes educacionais brasileiras, como a LDB (Lei de Diretrizes e Bases da Educação Nacional), que preconiza, em seu artigo primeiro e inciso segundo, que "a educação escolar deverá vincular-se ao mundo do trabalho e à prática social".

Com foco na aprendizagem significativa do aluno, os jesuítas buscaram compor materiais pedagógicos que contemplassem as demandas dos alunos. Devido a isso, tiveram grande preocupação em confeccionar materiais didáticos que visassem não somente ao auxílio do professor, como a gramática de Manuel Álvares, que precisou ser suprimida por causa dos diversos comentários filológicos, mas também ao auxílio do aluno, mostrando-o como fazer uso dos materiais. A adaptação dos materiais para atender ao público pode ser vista nas três edições portuguesas da gramática de Clenardo, que sintetizam ainda mais a língua grega para os alunos.

Por fim, o pensamento linguístico na classe inferior de gramática acompanha as prerrogativas de sua época e se alicerça num modelo gramatical há muito difundido, o da tradição latina.

\title{
Referências
}

\author{
ÁLVARES, Manuel. De Institutione Grammatica libri tres. Lisboa: João \\ Barreira, 1572.
}

ANCHIETA, José de. Cartas, informações, fragmentos históricos e sermões do Padre Joseph Anchieta, SL (1554-1594). Rio de Janeiro: Civilização brasileira AS, 1933.

BRASIL. Ministério de Educação e Cultura. LDB - Lei no 9394/96, de 20 de dezembro de 1996. Estabelece as diretrizes e bases da Educação Nacional. 
Brasília: MEC, 1996. Disponível em: http://www.planalto.gov.br/ccivil_03/ leis/19394.htm. Acesso em: 22 de maio de 2020.

CARDOSO, Simão. A gramática latina no séc. XVI: as $<<$ partes orationis $>>$ na gramática do P.e Manuel Álvares (1572) e na Minerva de Sanctius (1587). Revista da Faculdade de Letras línguas e Literaturas. v. 12, p. 159-172, Porto, 1995.

COMPANHIA DE JESUS. Constituições da Companhia de Jesus e normas complementares. São Paulo: Edições Loyola, 2004.

FERNANDES, Gonçalo. De Institutione Grammatica Libri Tres (1572) de Manuel Álvares (1526-1583). Revista da Academia Brasileira de Filologia. v. 4, p. 85-99, Rio de Janeiro, 2007.

FRANCA, Leonel. O método pedagógico dos jesuítas. Rio de Janeiro: Agir, 1952.

FRANCA, Leonel. O método pedagógico dos jesuítas: o Ratio Studiorum. São Paulo: Kírion, 2019.

HANSEN, João Adolfo. Manuel da Nóbrega. Recife: Fundação Joaquim Nabuco, Editora Massangana, 2010. Coleção Educadores.

JACA, Carlos. Situação da Universidade no período anterior à sua transferência para Coimbra. In: Diário do Minho - Linhas Gerais sobre a História da Universidade Conimbricense. Das suas origens à Reforma Universitária Pombalina de 1772. p. 1-37, 2010.

KEMMLER, Rolf. De institvtione grammatica libri tres (Lisboa, 1573): a edição princeps da ars minor de Manuel Álvares. Revista Portuguesa de Humanidades. v. 17, Braga: 2013.

KOERNER, E. F. Konrad. Quatro décadas de historiografia linguística: estudos selecionados. Trad. Cristina Altman, Sónia Coelho, Susana Fontes, Rolf Kemmler et all. Braga: 2014. 
LEITE, Serafim. História da Companhia de Jesus no Brasil. Tomo I. Tipografia Porto Médico, 1938.

LOYOLA, Ignacio de. Autobiografia de Santo Inácio de Loiola. Trad. António José Coelho, S.J. Braga: Editorial A. O., 2005.

MIRANDA, Margarida. O Padre Manuel Álvares e a primeira gramática global. In: Diocese do Funchal - A Primeira Diocese Global: História, Cultura e Espiritualidades. Volume 2, p. 505-513, Funchal: Esfera do Caos, 1995.

MORAIS, Carlos. As artes de gramática ex Clenardo para o ensino do Grego em Portugal. In: As Artes de Prometeu: Estudos em Homenagem a Ana Paula Quintela. Org. Belmiro Fernandes Pereira e Marta Várzeas. Faculdade de Letras da Universidade do Porto, 2009. P. 117-134.

NAVARRO, Eduardo de A. O ensino da gramática latina, grega e hebraica no Colégio das Artes de Coimbra no tempo de Anchieta. Actas do Congresso Internacional Anchieta em Coimbra - Colégio das Artes da Universidade (1548-1998). v.1, p. 385-406, Coimbra: Fundação Eng. António de Almeida, 2000.

ROSA, Teresa Maria R. da F. Monumenta historica O Ensino e a Companhia de Jesus (séculos XVIi a XVIII)Volume I (1540-1580). Instituto de Educação da Universidade de Lisboa, 2015.

SPRINGHETTI, Emilio. Storia e fortuna della Grammatica di Emmanuele Alvares, S. J. Humanitas. 13-14, Coimbra, 1961-1962.

STORCK, João Batista. Do modus parisiensis ao Ratio Studiorum: os jesuítas e a educação humanista no início da idade moderna. Hist. Educ., Santa Maria, v. 20, n. 48, p. 139-158, Apr. 2016.

SWIGGERS, Pierre. A historiografia da linguística: objeto, objetivos, organização. Confluência. Rio de Janeiro, n. 44-45, p. 1-21, $1^{\circ}$ e $2^{\circ}$ semestres de 2014. 